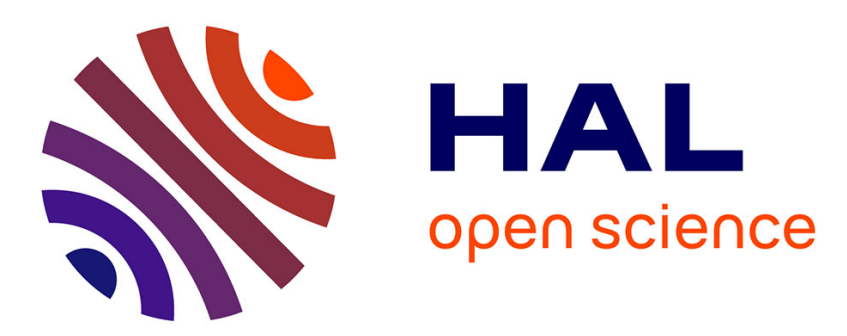

\title{
Proficiency study for the determination of nitrofuran metabolites in shrimps.
}

\author{
Dominique Hurtaud-Pessel, Eric Verdon, Jérôme Blot, Pascal Sanders
}

\section{To cite this version:}

Dominique Hurtaud-Pessel, Eric Verdon, Jérôme Blot, Pascal Sanders. Proficiency study for the determination of nitrofuran metabolites in shrimps.. Food additives and contaminants, 2006, 23 (6), pp.569-578. 10.1080/02652030500460534 . hal-00606203

\section{HAL Id: hal-00606203 \\ https://hal-anses.archives-ouvertes.fr/hal-00606203}

Submitted on 5 Jul 2011

HAL is a multi-disciplinary open access archive for the deposit and dissemination of scientific research documents, whether they are published or not. The documents may come from teaching and research institutions in France or abroad, or from public or private research centers.
L'archive ouverte pluridisciplinaire HAL, est destinée au dépôt et à la diffusion de documents scientifiques de niveau recherche, publiés ou non, émanant des établissements d'enseignement et de recherche français ou étrangers, des laboratoires publics ou privés. 


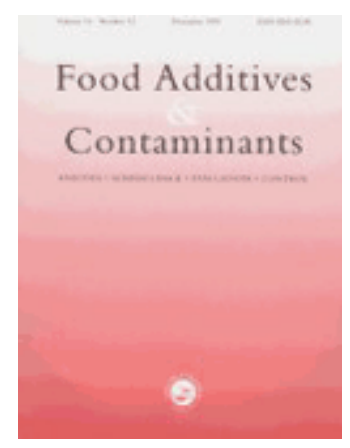

\section{Proficiency study for the determination of nitrofuran metabolites in shrimp}

\begin{tabular}{|c|c|}
\hline Journal: & Food Additives and Contaminants \\
\hline Manuscript ID: & TFAC-2005-078.R1 \\
\hline Manuscript Type: & Original Research Paper \\
\hline $\begin{array}{r}\text { Date Submitted by the } \\
\text { Author: }\end{array}$ & 27-Jun-2005 \\
\hline Complete List of Authors: & $\begin{array}{l}\text { hurtaud-pessel, dominique; AFSSA, LERMVD } \\
\text { Verdon, Eric; afssa, lermvd } \\
\text { blot, jerome; AFSSA, nancy } \\
\text { Sanders, Pascal; afssa, lermvd; AFSSA, LERMVD }\end{array}$ \\
\hline Methods/Techniques: & Proficiency testing, LC/MS \\
\hline Additives/Contaminants: & Veterinary drug residues \\
\hline Food Types: & Fish and fish products \\
\hline
\end{tabular}

\section{SCHOLARONE ${ }^{\text {m }}$ Manuscripts}


Table 1 : Results of the analysis of variance for the homogeneity study.

\begin{tabular}{|c|c|c|c|c|c|}
\hline & Source of variation & $\begin{array}{l}\text { Sum of } \\
\text { square }\end{array}$ & df & Mean-square & F-ratio \\
\hline \multirow{2}{*}{ Mat 4 - AOZ } & Between containers & 0.2794 & 9 & 0.031 & 1.03 \\
\hline & Analytical & 0.3 & 10 & 0.030 & \\
\hline \multirow[t]{2}{*}{ Mat $5-\mathrm{AOZ}$} & Between containers & 299.65 & 9 & 33.294 & 1.13 \\
\hline & Analytical & 294.4 & 10 & 29.437 & \\
\hline \multirow[t]{2}{*}{ Mat 5 -SEM } & Between containers & 0.55 & 9 & 0.061 & 4.21 \\
\hline & Analytical & 0.1 & 10 & 0.014 & \\
\hline \multirow[t]{2}{*}{ Mat 6 - AOZ } & Between containers & 5.27 & 9 & 0.585 & 0.71 \\
\hline & Analytical & 8.2 & 10 & 0.822 & \\
\hline \multirow[t]{2}{*}{ Mat 6 -SEM } & Between containers & 2.86 & 9 & 0.317 & 0.91 \\
\hline & Analytical & 3.5 & 10 & 0.350 & \\
\hline \multirow[t]{2}{*}{ Mat 7 - AOZ } & Between containers & 0.091 & 9 & 0.010 & 0.18 \\
\hline & Analytical & 0.6 & 10 & 0.0570 & \\
\hline
\end{tabular}

Critical value of $F\left(p=0.05, v_{1}=9, v_{2}=10\right)$ is 3.02 . 
Table 2 : characteristics of the methods used.

\begin{tabular}{|c|c|c|c|c|c|c|c|c|c|c|c|}
\hline \multirow{2}{*}{$\begin{array}{l}\text { Lab. } \\
\text { code }\end{array}$} & \multirow{2}{*}{ Technique } & \multirow{2}{*}{$\begin{array}{c}\text { Calibration range } \\
\mu \mathrm{g} / \mathrm{kg} \text { (Number of } \\
\text { levels) }\end{array}$} & \multirow{2}{*}{$\begin{array}{l}\text { Internal } \\
\text { standard }\end{array}$} & \multicolumn{4}{|c|}{$\mathrm{CC} \alpha(\mu \mathrm{g} / \mathrm{kg})$} & \multicolumn{4}{|c|}{$C C B(\mu \mathrm{g} / \mathrm{kg})$} \\
\hline & & & & $\mathrm{AOZ}$ & AMOZ & SEM & $\mathrm{AHD}$ & $\mathrm{AOZ}$ & AMOZ & SEM & AHD \\
\hline$A$ & LC/MS-MS & $0.1-60$ & $\begin{array}{c}\text { D4-AOZ } \\
\text { D5-AMOZ }\end{array}$ & 0.7 & 0.7 & 0.7 & 0.7 & 1 & 1 & 1 & 1 \\
\hline B & LC/MS-MS & $0.25-5$ & $\begin{array}{c}\text { D4-AOZ } \\
\text { D5-AMOZ }\end{array}$ & $0.3^{\#}$ & $0.3^{\#}$ & $1^{\#}$ & $1^{\#}$ & & & & \\
\hline $\mathrm{H}$ & LC/MS-MS & $0-5 \quad(7)$ & $\begin{array}{c}\text { D4-AOZ } \\
\text { D5-AMOZ }\end{array}$ & $0.5^{\circ}$ & $0.5^{\circ}$ & $0.5^{\circ}$ & $0.5^{\circ}$ & & & & \\
\hline L & LC/MS-MS & $0.5-2$ & $\begin{array}{c}\text { D4-AOZ } \\
\text { D5-AMOZ }\end{array}$ & 0.10 & 0.17 & 0.22 & 0.18 & 0.26 & 0.30 & 0.39 & 0.33 \\
\hline M & LC/MS-MS & $0-10$ & $\begin{array}{c}\text { D4-AOZ } \\
\text { D5-AMOZ }\end{array}$ & 0.5 & 0.5 & 0.5 & 0.5 & 0.5 & 0.5 & 1.2 & 0.5 \\
\hline $\mathrm{N}$ & LC/MS-MS & $0-5 \quad$ (5) & $\begin{array}{c}\text { D4-AOZ } \\
\text { D5-AMOZ }\end{array}$ & 0.23 & 0.77 & 0.17 & 0.77 & 0.6 & 0.83 & 1.06 & 1.07 \\
\hline$P$ & $\mathrm{LC} /(\mathrm{MS})^{\mathrm{n}}$ & $0.5-5 \quad(4)$ & $\begin{array}{c}\text { D4-AOZ } \\
\text { D5-AMOZ }\end{array}$ & & & & & & & & \\
\hline$S$ & LC/MS-MS & $\begin{array}{c}0-7 \mathrm{AOZ} \\
0-1.5 \mathrm{SEM}\end{array}$ & $\begin{array}{c}\text { D4-AOZ } \\
\text { D5-AMOZ } \\
\mathrm{C}_{13} \mathrm{~N}_{15^{-}} \\
\mathrm{N}_{15} \mathrm{SEM}\end{array}$ & & & & & & & & \\
\hline$T$ & $\mathrm{LC} /(\mathrm{MS})^{\mathrm{n}}$ & $1-25 \quad(5)$ & D5-AMOZ & & 0.5 & & & & 0.7 & & \\
\hline$U$ & LC/MS-MS & $\begin{array}{l}0.1-4.0 \quad(6) \\
\text { AOZ, AMOZ } \\
0.33-13.36 \quad(6) \\
\text { SEM, AHD }\end{array}$ & D5-AMOZ & $0.3^{+}$ & $0.3^{+}$ & $1^{+}$ & $1^{+}$ & & & & \\
\hline V & LC/MS-MS & $0-5 \quad(5)$ & $\begin{array}{c}\text { D4-AOZ } \\
\text { D5-AMOZ }\end{array}$ & 0.3 & 0.3 & 0.5 & 0.5 & 0.4 & 0.4 & 0.8 & 0.8 \\
\hline W & LC/MS-MS & $\begin{array}{c}0-10 \text { or } 0-50 \\
(6 \text { or } 7)\end{array}$ & D4-AOZ & 0.18 & 0.07 & 0.37 & 0.47 & 0.51 & 0.31 & 0.71 & 1.91 \\
\hline$x$ & $\mathrm{LC} /(\mathrm{MS})^{\mathrm{n}}$ & $0.25-10 \quad(7)$ & $\begin{array}{c}\text { D4-AOZ } \\
\text { D5-AMOZ }\end{array}$ & 0.1 & 0.1 & 0.1 & 0.1 & & & & \\
\hline Z & LC/MS-MS & $0.125-2.0$ & $\begin{array}{c}\text { D4-AOZ } \\
\text { D5-AMOZ }\end{array}$ & 0.12 & 0.13 & 0.25 & 0.30 & 0.17 & 0.25 & 0.37 & 0.41 \\
\hline$E^{a}$ & LC/MS & $5-50 \quad(6)$ & $\mathrm{D} 4-\mathrm{AOZ}$ & 3.8 & & & & 8 & & & \\
\hline$F$ & LC/MS-MS & $0.25-5$ & $\begin{array}{c}\text { D4-AOZ } \\
\text { D5-AMOZ }\end{array}$ & $0.2^{+}$ & $0.2^{+}$ & $0.5^{+}$ & $0 .^{+} 5$ & & & & \\
\hline C & LC/MS-MS & $1-10 \quad(4)$ & No & 0.2 & 0.2 & 0.2 & 0.2 & 0.5 & 0.5 & 0.5 & 0.5 \\
\hline $\mathrm{K}$ & LC/MS & $2-50$ & No & $0.3^{\circ}$ & $0.3^{\circ}$ & $0.3^{\circ}$ & $0.3^{\circ}$ & $\begin{array}{c}0.7^{*} \\
1^{+}\end{array}$ & $\begin{array}{c}0.7^{*} \\
1^{+}\end{array}$ & $\begin{array}{l}1^{*} \\
2^{+}\end{array}$ & $\begin{array}{c}0.7^{*} \\
1^{+}\end{array}$ \\
\hline$Q$ & $\mathrm{LC} /(\mathrm{MS})^{\mathrm{n}}$ & $0.5-5$ & $\begin{array}{c}\text { D4-AOZ } \\
\text { D5-AMOZ }\end{array}$ & $1^{\circ}$ & $1^{\circ}$ & $1^{\circ}$ & & 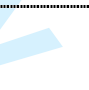 & & & \\
\hline $\mathrm{R}$ & $\mathrm{LC} /(\mathrm{MS})^{\mathrm{n}}$ & $0.5-5$ & $\begin{array}{c}\text { D4-AOZ } \\
\text { D5-AMOZ }\end{array}$ & & & & & & & & \\
\hline
\end{tabular}

": determination of $A O Z$ only.

\# : decision limit based on lowest level of validation

${ }^{+}$: limits of reporting

$\circ: L O D$

$*: \angle O Q$

empty field : no data available 
Table 3 : assigned values $(\mu \mathrm{g} / \mathrm{kg})$ and their standard deviation in test materials.

\begin{tabular}{|c|c|c|c|c|}
\hline & $\mathrm{AOZ}$ & AMOZ & SEM & AHD \\
\hline Material 1 & - & - & - & - \\
\hline Material 2 & - & - & - & - \\
\hline Material 3 & - & - & - & - \\
\hline \multicolumn{5}{|l|}{ Material 4} \\
\hline Assigned value $(\mu \mathrm{g} / \mathrm{kg})$ & 1.2 & - & - & - \\
\hline Standard deviation $(\mu \mathrm{g} / \mathrm{kg})$ & 0.5 & & & \\
\hline Relative standard deviation (\%) & 42 & & & \\
\hline Number of data & 16 & & & \\
\hline \multicolumn{5}{|l|}{ Material 5} \\
\hline Assigned value $(\mu \mathrm{g} / \mathrm{kg})$ & 32.1 & - & 1.3 & - \\
\hline Standard deviation $(\mu \mathrm{g} / \mathrm{kg})$ & 16.1 & & 0.6 & \\
\hline Relative standard deviation (\%) & 50.1 & & 41.7 & \\
\hline Number of data & 18 & & 14 & \\
\hline \multicolumn{2}{|l|}{ Material 6} & \multicolumn{2}{|c|}{$\sqrt{a-2}$} & \\
\hline Assigned value $(\mu \mathrm{g} / \mathrm{kg})$ & 7.9 & - & 1.4 & - \\
\hline Standard deviation $(\mu \mathrm{g} / \mathrm{kg})$ & 4.2 & & 0.6 & \\
\hline Relative standard deviation (\%) & 52.9 & & 47.1 & \\
\hline Number of data & 18 & & 13 & \\
\hline \multicolumn{5}{|l|}{ Material 7} \\
\hline Assigned value $(\mu \mathrm{g} / \mathrm{kg})$ & 0.9 & - & - & - \\
\hline Standard deviation $(\mu \mathrm{g} / \mathrm{kg})$ & 0.3 & & & \\
\hline Relative standard deviation (\%) & 36.3 & & & \\
\hline Number of data & 15 & & & \\
\hline
\end{tabular}


Table 4 :

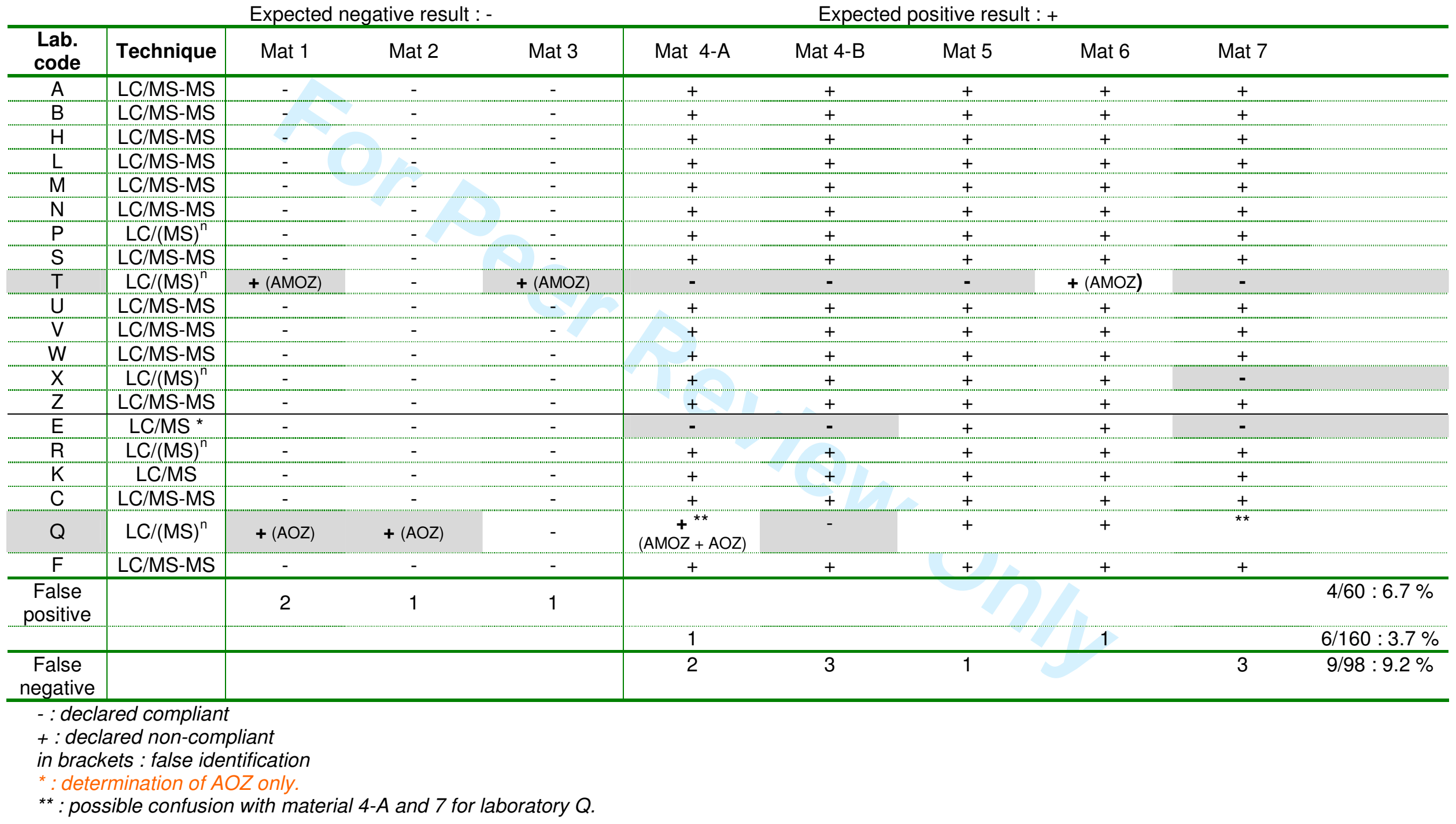


Table 5 :Z-scores for contaminated samples

\begin{tabular}{|c|c|c|c|c|c|c|c|c|c|c|}
\hline \multirow[b]{3}{*}{ LAB } & \multicolumn{4}{|c|}{ AOZ $1.2 \mu \mathrm{g} / \mathrm{kg}$} & \multirow{2}{*}{\multicolumn{2}{|c|}{$\begin{array}{c}\text { AOZ } 0.9 \mu \mathrm{g} / \mathrm{kg} \\
\text { Mat } 7\end{array}$}} & \multirow{2}{*}{\multicolumn{2}{|c|}{$\begin{array}{c}\text { SEM } 1.3 \mu \mathrm{g} / \mathrm{kg} \\
\text { Mat } 5\end{array}$}} & \multirow{2}{*}{\multicolumn{2}{|c|}{$\begin{array}{c}\text { SEM } 1.4 \mu \mathrm{g} / \mathrm{kg} \\
\text { Mat } 6\end{array}$}} \\
\hline & \multicolumn{2}{|c|}{ Mat 4-1 } & \multicolumn{2}{|c|}{ Mat 4-2 } & & & & & & \\
\hline & $\begin{array}{c}\mathrm{Za} \\
(\sigma=0.25)\end{array}$ & $\begin{array}{c}\mathrm{Zr} \\
\left(\sigma_{r}=0.17\right)\end{array}$ & $\begin{array}{c}\mathrm{Za} \\
(\sigma=0.25)\end{array}$ & $\begin{array}{c}\mathrm{Zr} \\
\left(\sigma_{r}=0.17\right)\end{array}$ & $\begin{array}{c}\mathrm{Za} \\
\left(\sigma_{r}=0.19\right)\end{array}$ & $\begin{array}{c}\mathrm{Zr} \\
\left(\sigma_{r}=0.13\right)\end{array}$ & $\begin{array}{c}\mathrm{Za} \\
\left(\sigma_{r}=0.29\right)\end{array}$ & $\begin{array}{c}\mathrm{Zr} \\
\left(\sigma_{r}=0.19\right)\end{array}$ & $\begin{array}{c}\mathrm{Za} \\
\left(\sigma_{r}=0.29\right)\end{array}$ & $\begin{array}{c}\mathrm{Zr} \\
\left(\sigma_{r}=0.19\right)\end{array}$ \\
\hline $\mathrm{X}$ & -3.2 & 1.2 & -3.4 & 1.7 & & & & & & \\
\hline U & -3.0 & 0.8 & -2.8 & 0.4 & -2.7 & 0.5 & -2.4 & 0.7 & -2.5 & 0.0 \\
\hline L & -1.6 & 0.5 & -1.7 & 0.5 & -1.5 & 0.2 & 7.9 & 18.3 & -1.7 & 0.4 \\
\hline $\mathrm{M}$ & -1.6 & 0.6 & -0.8 & 1.2 & -1.4 & 0.0 & & & & \\
\hline $\mathrm{F}$ & -1.0 & 0.8 & -1.4 & 0.0 & & & & & & \\
\hline $\mathrm{K}$ & -0.9 & 0.5 & -1.2 & 0.1 & -1.3 & 0.4 & -2.6 & 1.1 & 1.8 & 7.7 \\
\hline $\mathrm{B}$ & -0.8 & 0.1 & -1.2 & 0.0 & -0.8 & 0.2 & 1.2 & 0.9 & 2.3 & 0.5 \\
\hline$S$ & -0.2 & 0.0 & -0.2 & 0.0 & -0.8 & 0.0 & -0.2 & 1.9 & -0.4 & 0.4 \\
\hline $\mathrm{N}$ & -0.2 & 1.4 & -0.4 & 0.8 & -0.3 & 0.8 & -1.7 & 0.5 & -2.2 & 0.5 \\
\hline $\mathrm{V}$ & 0.4 & 1.2 & 0.0 & 2.1 & -0.3 & 1.1 & -0.4 & 0.0 & -0.7 & 0.4 \\
\hline $\mathrm{H}$ & 0.8 & 1.2 & 1.4 & 2.5 & 1.5 & 0.5 & 2.4 & 7.4 & 2.0 & 7.4 \\
\hline Z & 0.8 & 0.4 & -0.6 & 0.0 & -0.3 & 0.3 & 1.0 & 0.7 & 0.5 & 0.0 \\
\hline $\mathrm{R}$ & 0.9 & 0.3 & 2.3 & 2.6 & 1.9 & 0.1 & 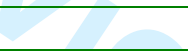 & & & \\
\hline$A$ & 1.2 & 1.2 & 3.0 & 3.3 & 1.5 & 1.6 & 6.5 & 3.7 & 3.5 & 0.0 \\
\hline$P$ & 4.6 & 3.3 & 1.8 & 1.7 & 0.5 & 1.6 & 0.0 & 0.7 & -1.2 & 1.4 \\
\hline W & 4.6 & 0.1 & 2.0 & 1.4 & 1.9 & 1.5 & 1.3 & 0.0 & 0.8 & 0.6 \\
\hline C & 4.8 & 0.4 & 4.8 & 1.2 & 2.8 & 0.0 & 0.1 & 2.6 & 1.0 & 0.4 \\
\hline$Q$ & & & & & & & -0.8 & 0.6 & $\Delta$ & \\
\hline $\begin{array}{l}\text { Satisfactory } \\
\text { Za-score } \\
(|z| \leq 2) \text { : } \\
\text { - Number of } \\
\text { lab } \\
\text { - Rate }\end{array}$ & & $/ 17$ & & & 13 & & 64 & $\%$ & & \\
\hline
\end{tabular}


Figure 1 : Stability study for AOZ.

Figure 2 : Stability study for SEM.

Figure 3 : Accuracy z-scores for material 4. Dotted line corresponds to zscore $=2$. Solid line corresponds to z-score $=3$.

Figure 4 : Accuracy z-scores for material 5.

Figure 5 : Accuracy z-scores for material 6.

Figure 6 : Accuracy z-scores for material 7. 
Fig 1

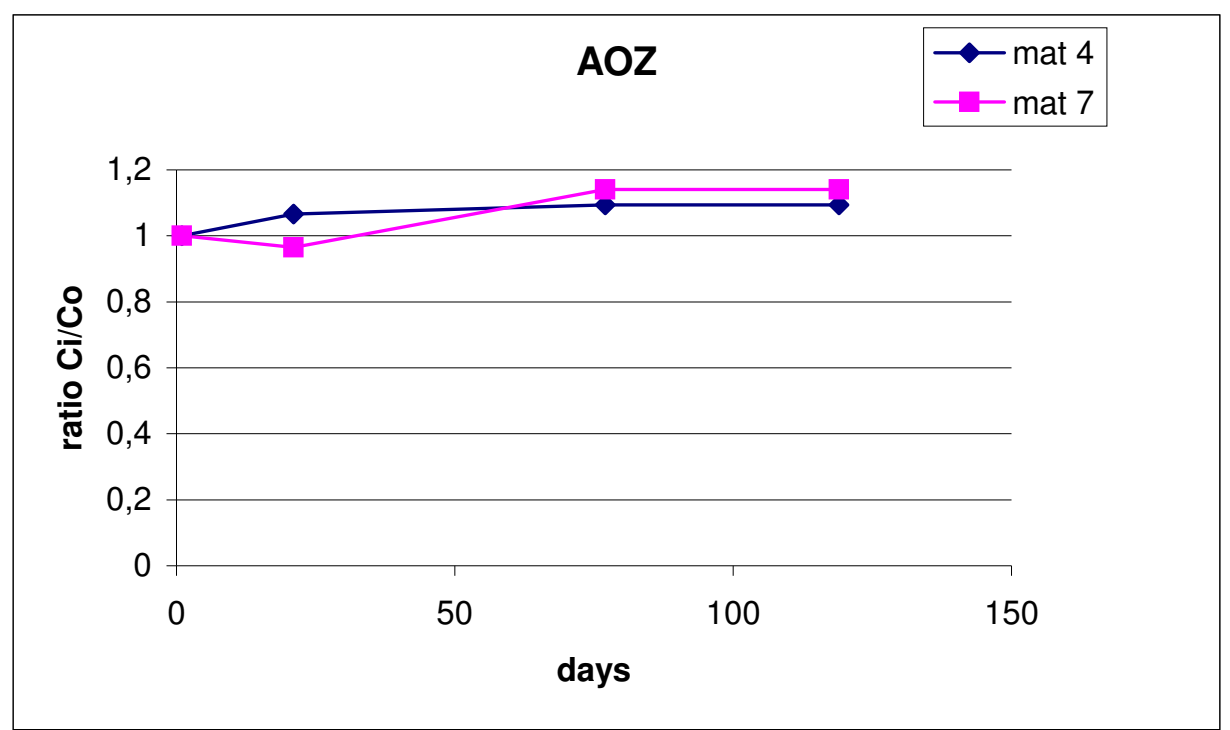

Fig 2

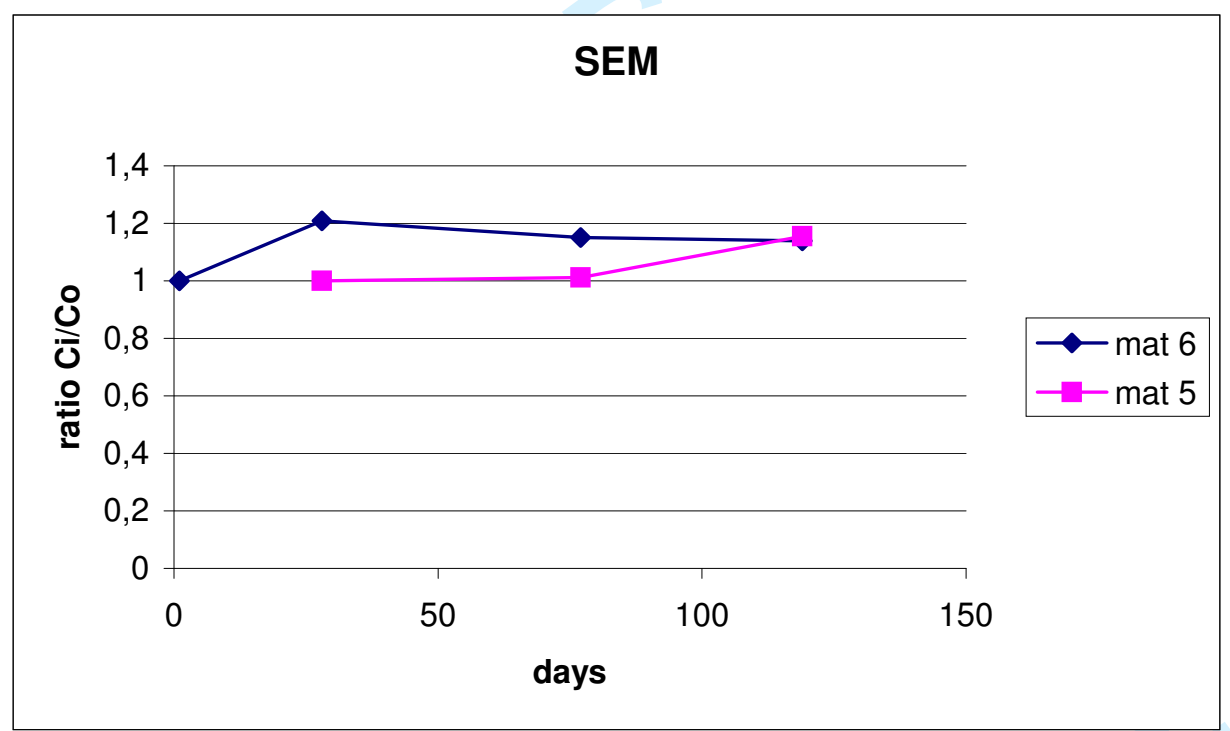


Fig 3

Material 4

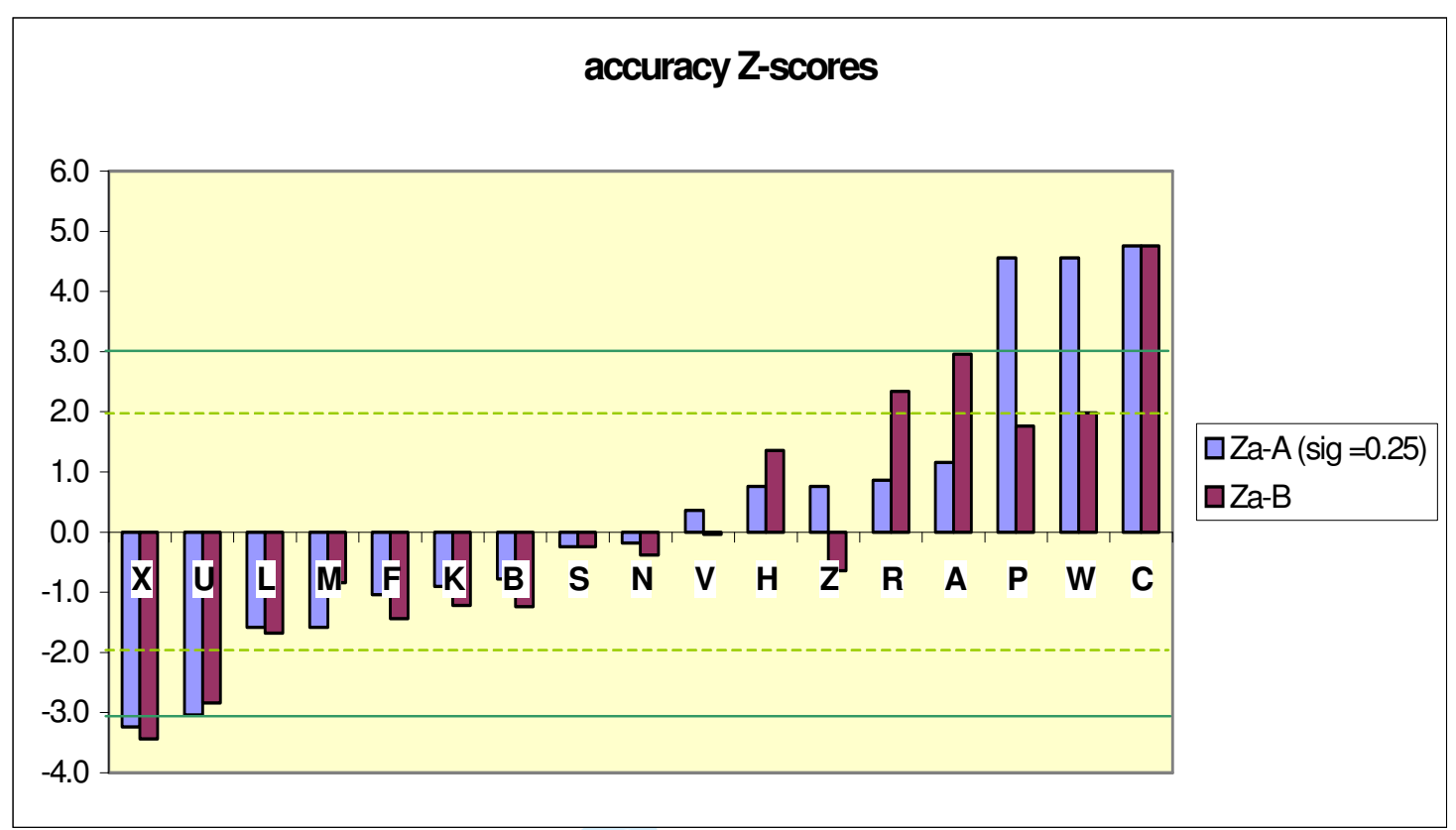

Fig 4

Material 5

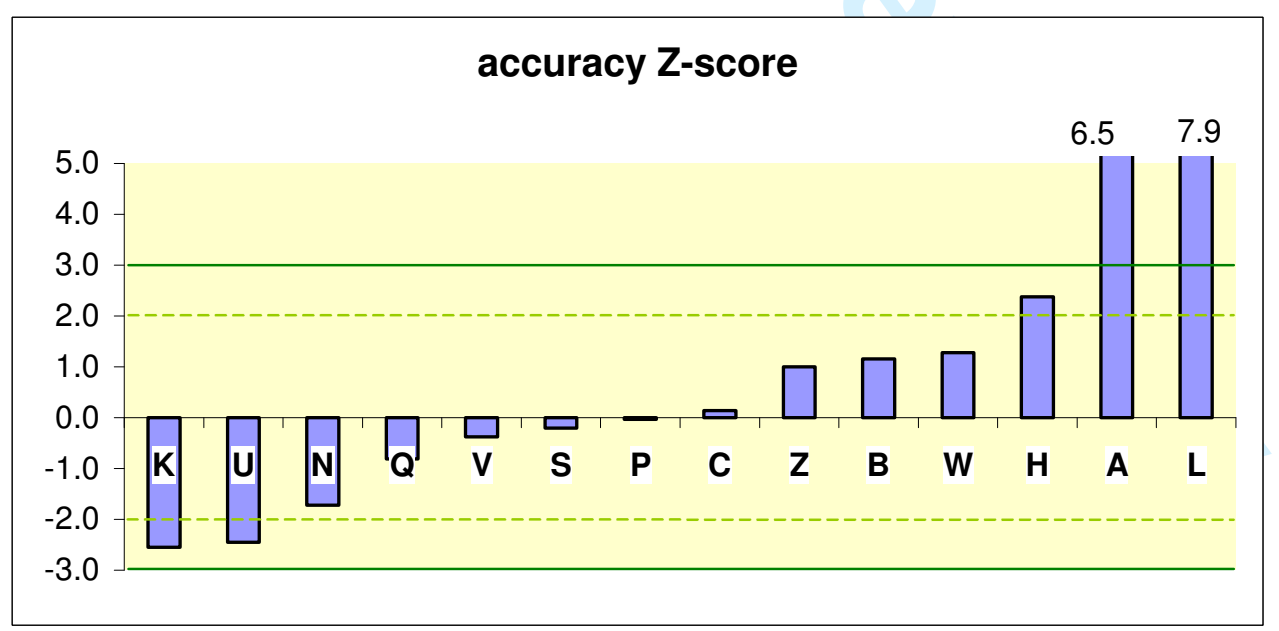


Fig 5

Material 6

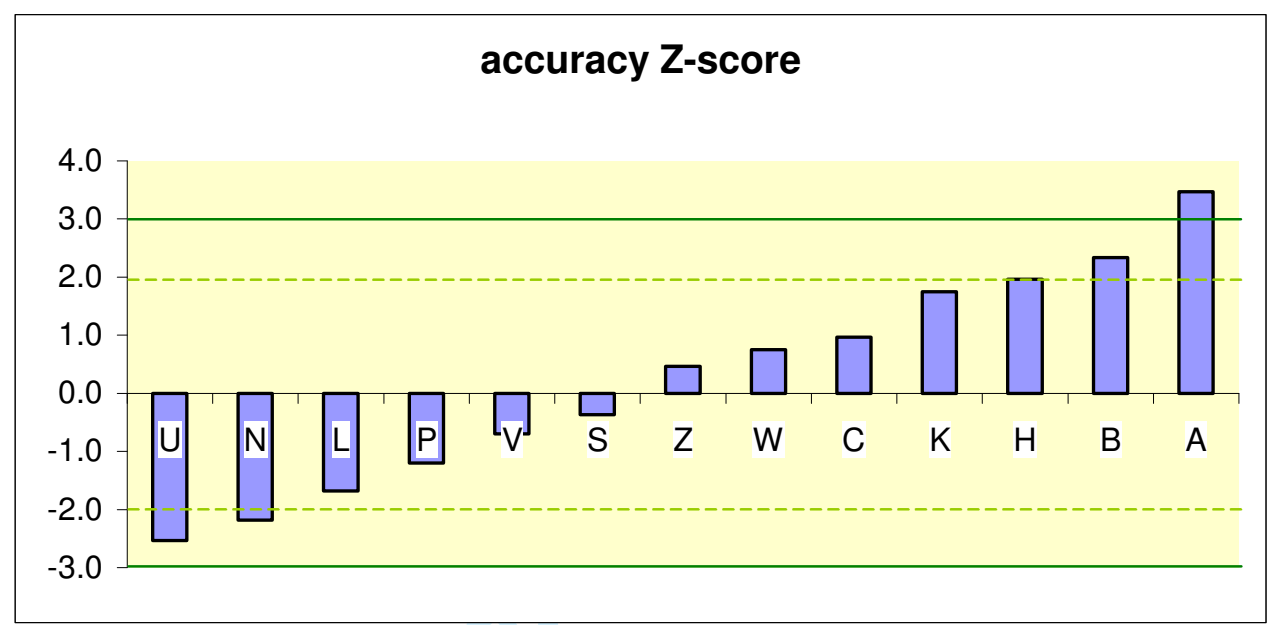

Fig 6

Material 7

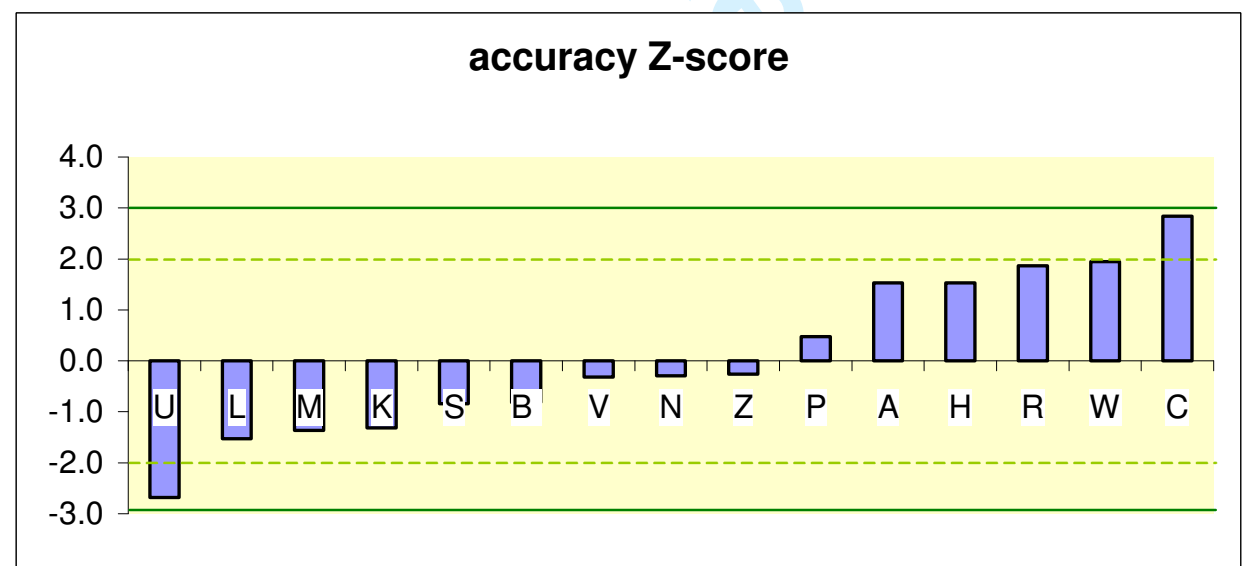




\title{
Proficiency study for the determination of nitrofuran metabolites in shrimps
}

\author{
D. HURTAUD-PESSEL, E. VERDON, J. BLOT, and P. SANDERS.
}

Agence Française de Sécurité Sanitaire des Aliments (AFSSA) - Laboratoire d'Etudes et de Recherches sur les Médicaments Vétérinaires et les Désinfectants (LERMVD), La haute marche, Javené BP 90203, F-35302 Fougères, France.

A proficiency test for the determination of nitrofuran metabolites in shrimp tissue was organised in the first half of 2003. This test was intended to allow the participants to use their routine method and to assess their competence on this specific analysis. The participation in this proficiency test was offered to all the National Reference Laboratories (NRLs) of the European Union (EU) in charge of the analysis of nitrofurans, to Official Laboratories of the then 10 Candidate Countries for entry in EU and to some countries exporting food to the EU. The participants (20) analysed nitrofuran metabolites in 8 randomly coded frozen samples including 3 blank samples. All participants performed a confirmatory method using liquid chromatography/mass spectrometry to detect total nitrofuran metabolite residues. Both qualitative and quantitative analysis of the results were investigated. Qualitatively, 16 laboratories out of 20 gave the correct interpretation of the results in term of compliant / non-compliant sample. Quantitatively, laboratory performance was evaluated by calculating the z-scores.

Keywords : nitrofurans, residues, LC-MS/MS analysis, proficiency, interlaboratory study, metabolites. 


\section{Introduction}

Nitrofurans are antibacterial agents that have been used as feed additives for cattle, pig and poultry. Since 1993 and 1995 (for furazolidone), the use of nitrofuran drugs (furazolidone, furaltadone, nitrofurazone, nitrofurantoin) was banned in EU for food animal production (Council regulation (EEC) No 2901/93, 1993, Commission Regulation (EC) No 1442/95, 1995). However, these substances are still in use in some other countries worldwide and residues of nitrofuran have been found in a wide range of food-animal products (poultry, aquaculture products, eggs). In March 2003, a definitive MRPL (Minimum Required Performance Limit) was set at $1 \mu \mathrm{g} / \mathrm{kg}$ in EU for these drugs in poultry and aquaculture products (Commission decision 2003/181/EC, 2003). So, all laboratories involved in the monitoring of nitrofuran residues have to reach at least this limit. Within the EU, the control of nitrofurans in food from animal products started ten years ago. The testing for residues of the parent drugs was ineffective because nitrofuran compounds are rapidly metabolized. In vivo, they formed stable and persistent tissue-bound residues. A few years ago, the ability of EU NRLs to test for tissue-bound nitrofuran residues was poor. This is why a liquid chromatography tandem mass spectrometry (LC-MS/MS) method developed through the FoodBrand EU project (QLK1-CT1999-00142, available from www.afsni.ac.uk/foodbrand) was transferred and most of the laboratories involved in the veterinary drug residue control in EU implemented this LCMS/MS method for screening and confirmation of nitrofuran residues in tissue. This method focused on AOZ (3-amino-2-oxazolidinone), AMOZ (3-amino-5morpholinomethyl-2-oxazolidinone), AHD (1-aminohydantoin) and SEM (semicarbazide) the marker residues of the nitrofuran banned parent drugs furazolidone, furaltadone, nitrofurantoin and nitrofurazone respectively. It is based on acid hydrolysis of protein-bound residues followed by the derivatization using nitrobenzaldehyde to lead to the nitrophenyl derivatives. The literature describes few methods using LC-MS/MS for the analysis of nitrofuran metabolites ( Leitner et al. 2001, Mottier et al2005, Cooper et al 
2005). Therefore, it became important that laboratories had the opportunity to test their ability to control nitrofurans and to prove the reliability of their result. As the organization of proficiency tests for European Union-National Reference Laboratories (EU-NRLs) is one of the tasks of the Community Reference Laboratory ( $C R L)$, a proficiency test for the analysis of nitrofurans was organized during the period February-July 2003. The participation in this test was offered to all EU-NRLs, but also to Official Laboratories of Candidate Countries for 2004 entry in EU and to some countries exporting food into EU. The study was conducted according to the recommendations of ISO guide 43-1 (1997). This paper reports the results of the first proficiency testing study for the determination of nitrofuran residues in shrimps.

\section{Experimental}

Sample material preparation.

Materials for the test were shrimps obtained from the French Border Inspection Services. 7 different batches of frozen raw shrimps were chosen as follows : 3 batches of shrimps where nitrofuran residues were found to be absent (i.e. below the LOD of 0.1 to $0.2 \mu \mathrm{g} / \mathrm{kg}$ depending on the nitrofuran) were selected as blank matrix and 4 other batches of shrimps were nitrofuran residues were found to be present were selected as naturally contaminated matrices. Shrimps from a same batch were thawed, deshelled and only the tails of the shrimps were minced. Each material was homogenized in a mixing bowl, sampled into containers $(10 \mathrm{~g})$ and stored at $-20^{\circ} \mathrm{C}$ until dispatching. Each container was randomly coded. One material (material 4) was sent blindly in duplicate samples. A total of eight frozen samples was shipped to each participant.

\section{Homogeneity and stability studies.}

Before sending the samples, it was necessary to test the materials for sufficient homogeneity. The sample homogeneity was determined for each contaminated material by analysing 10 randomly selected containers in duplicate and comparing the sampling variance to the analytical variance, according to the 'International Harmonised Protocol for Proficiency Testing of (Chemical) 
Analytical Laboratories' (Thompson et al. 1993). For each material, the procedure was carried out as follows : 10 containers were randomly selected among the containers stored at $-20^{\circ} \mathrm{C}$ and thawed at room temperature. 2 test portions were taken from each container and the analysis of the $2 \times 10$ portions were carried out under the same day. The samples were analysed by the CRLAFSSA Fougères using the LC/MS-MS method. Homogeneity was assessed by means of a one-way analysis of variance (ANOVA) of the concentration values. The results are given in table 1.

The analysis of variance proved that the materials were found to be homogeneous. The statistical F-test showed that the sampling variance doesn't differ from the analytical variance with $5 \%$ risk assessment ( $F$-ratio $<\mathrm{F}$ critical) except for SEM in material 5 . For this material, although the ratio of the sampling variance Ss / $\sigma=0.4$ (where Ss is the sampling variance and $\sigma$ is the target value for reference standard deviation derived from Horwitz equation) is higher than the recommended value 0.3 , it was decided to use it for proficiency study, as the material was homogeneous for $\mathrm{AOZ}$.

[insert table 1 about here]

Stability studies were performed during the proficiency test to prove that the analyte content did not significantly change with regard to analytical variations. The materials were analysed at different time over a period of 3 months being stored at $-20^{\circ} \mathrm{C}$. The ratio $\mathrm{Ci} / \mathrm{Co}$ was determined for each period : $\mathrm{Ci}$ was the concentration at the time $\mathrm{Ti}$ and $\mathrm{Co}$ was the concentration at initial time To. The time To was the day of the first analysis carried out at CRL-AFSSA Fougères during the period of the interlaboratory study. No loss of $A O Z$ or SEM content could be observed during this period under storage at $-20^{\circ} \mathrm{C}$ (see figures 1-2).

[insert figures 1 and 2 about here]

\section{Results and discussion}

The participants were asked to analyse the 8 samples for their possible content of nitrofuran metabolites using the method of their choice. Each sample had to be analysed in duplicate. Detected nitrofurans had to be quantified and confirmed according to Commission Decision 2002/657/EC (2002). Moreover, 
for each sample, participants had to give an interpretation of the result as compliant or non-compliant in line with Decision 2002/657/EC. 20 laboratories participated to the study : 14 were EU-NRLs and 6 were outside EU laboratories (in 2003).

\section{Methods and analytical techniques.}

All participants used LC/MS to analyse the samples but with different mass instruments : LC/MS single quadrupole (10\%), LC/(MS) ${ }^{\mathrm{n}}$ ion trap (25\%) and LC/MS-MS triple quadrupole (65\%).

All methods used to detect total nitrofuran metabolite residues were based on the following principle : hydrolysis and derivatization with nitro-benzaldehyde during one night at $37^{\circ} \mathrm{C}$, extraction of the nitrophenyl derivatives, evaporation and reconstitution of the sample before injection. Most of the participants took advantage of deuterated internal standards. The analytical characteristics of the methods are displayed in table 2. Not all the participants gave the analytical limits of their method. One can observe that, except for laboratory $E$, the limits of decision CC $\alpha$ comply with the MRPL of $1 \mu \mathrm{g} / \mathrm{kg}$. However, the participants did not give informations on the way they calculated the limits. Depending on the participant, the given limit is either the limit of reporting, either the lowest level of validation or either the limit of detection.

\section{Assigned values.}

The assigned values of the materials were determined as a consensus value of the results of all participants (except one laboratory for its extra-deadline sending of results). They were calculated as the robust average of the results, as it is described in the Annex C of ISO/DIS 13528 (2000). The robust estimates of $x^{*}$ and $s^{*}$ are derived by an iterative calculation, updating the values of $x^{*}$ and $s^{*}$ several times, until the process converges. This calculation provides robust values of the average and standard deviation of the data to which it is applied with no need to discard any of the data. The results are given in Table 3.

[insert table 3 about here] 


\section{Qualitative analysis}

Participants analysed the samples for the presence of the 4 metabolites : AHD, AOZ, AMOZ and SEM. One participant analysed only for AOZ. Table 5 shows laboratory qualitative results. For a blank sample, the expected result is (compliant) and for a contaminated sample, the expected result is + (non compliant).

Over the 20 participants, only two laboratories ( $T$ and $Q$ ) found false positive results. They confirmed the presence of $A M O Z$ and $A O Z$ in materials 1, 2 or 3 with LOD of $0.5 \mu \mathrm{g} / \mathrm{kg}$ for laboratory $T$ and $1 \mu \mathrm{g} / \mathrm{kg}$ for laboratory $Q$. The LOD of the others participants are nearly all inferior. For the blank samples, the rate of false positive is $6.7 \%$. For the contaminated sample, the determination of an analyte which is actually not present counted also as a false positive result. It is the case both for material 6 and material 4 for which laboratory T and laboratory $Q$ respectively, confirmed $A M O Z$ instead of $A O Z$. Considering these samples, the rate of false positive is $3.7 \%$. Usually, the false positive result can often be explained by cross-contamination between samples. Among the 8 samples sended, one sample (material 5) was highly contaminated with AOZ ( 30 $\mu \mathrm{g} / \mathrm{kg}$ )and might lead to cross-contamination. For laboratory $\mathrm{T}$ finding three AMOZ contaminated samples and for laboratory $Q$ finding one AMOZ contaminated sample, no explanation is proposed.

Taking into account that, when SEM and AOZ were both present in a material, only one of them had to be detected to declare the sample as no-compliant, it is assumed that the rate of false negative is approximately $9 \%$. Laboratory $E$ found 3 false negative results. Obviously the 3 samples with contaminated level around $1 \mu \mathrm{g} / \mathrm{kg}$ were not confirmed because of the inadequate limit of its method $(\mathrm{CC} \alpha=3.8 \mu \mathrm{g} / \mathrm{kg})$. Laboratories $\mathrm{T}, \mathrm{X}$ and $\mathrm{Q}$ gave also false negative results.

[insert table 4 about here]

Quantitative analysis 
The statistical approach used for the analysis of the results was based on the zscore [ISO, 1997].

The accuracy $z$-score was given by : $Z a=(x-\hat{X}) / \sigma$ where $Z_{a}$ is the "accuracy z-score", $x$ is the laboratory result (mean of the duplicate analyses), $\hat{X}$ is the assigned value and $\sigma$ is the target value for standard deviation. The target value for standard deviation $\sigma$ was determined according to the equation proposed by M. Thompson (2000) : $\sigma=0.22 c$ if $c<1.2 \times 10^{-7} .(\equiv 120 p p b)$ where $c$ is the concentration..

As each laboratory analysed every material in duplicate, repeatability z-score was also calculated as : $\mathrm{Zr}=\mathrm{SD} / \sigma_{\mathrm{r}}$ where $\mathrm{Zr}$ is the "repeatability $\mathrm{z}$-score", SD is the standard deviation of the 2 results and $\sigma_{r}$ is the target value for standard deviation determined as follows : $\sigma_{r}=2 / 3 \sigma^{* *}$

** When the analyses are carried out under repeatability conditions, the Commission decision 2002/657/CE (2002) specifies that the intralaboratory RSD to be between one-half and two third of the reproducibility $\mathrm{RSD}$.

The z-scores give a numerical approach of the performance of a laboratory in a proficiency test. It allows a classification as follows :

$$
\begin{array}{ll}
|Z| \leq 2 \Rightarrow & \text { Satisfactory } \\
2<|Z|<3 & \text { Questionable } \\
|Z| \geq 3 \Rightarrow \text { Unsatisfactory }
\end{array}
$$

The z-score values have not been calculated for AOZ content in material 5 and 6 because the high values of $\mathrm{AOZ}$ (32.1 and $7.9 \mu \mathrm{g} / \mathrm{kg}$ respectively) reported by the participants came for most of them from extrapolation of a too short calibration range, usually centred around the MRPL level concentration of 1 $\mu \mathrm{g} / \mathrm{kg}$. Even if it would be expected that a calibration curve should be made in a range which covers all the samples analysed, many participants focused on the accuracy at the MRPL level. Extra high concentration has not practical 
importance from the point of the possible legal action. The accuracy of the quantification beyond $2 \mathrm{MRPL}$ is of lesser importance in the case of banned substances. For that, the z-scores were only calculated for SEM content of these materials 5 and 6 and for AOZ content of material 4 and 7. Table 5 displays an overview of the $z$-scores. Histograms presenting the data for accuracy z-scores are given in figures 3-6.

[insert table 5 about here]

[insert figures 3-6 about here]

Material $4(1.2 \mu \mathrm{g} / \mathrm{kg} \mathrm{AOZ})$ was sent in duplicate blindly. From figure 3 , for this material, it is noteworthy that 4 laboratories $(R, A, P$ and $W$ ) have obtained very different Za-scores for the two identical samples. For material $7(0.9 \mu \mathrm{g} / \mathrm{kg}$ AOZ), none Za-scores are unsatisfactory and 13 over 15 are satisfactory. For materials containing SEM ( 5 and 6 ), 2 laboratories ( $A$ and $L$ ) are involved in high Za-score values. Laboratory A obtained unsatisfactory results both for material 5 and material 6 . For laboratory $L$ which obtained a high Za-score for material 5 , this value could be due to a bad repeatability in the analysis done in duplicate, shown by a high Zr-score.

Considering only the participants who gave quantitative results (excluding the false positive and the false negative responses), the global z-score evaluation showed that:

- the rate of laboratories producing a satisfactory accuracy z-score for total AOZ content around the MRPL (between 0.9 and $1.2 \mu \mathrm{g} / \mathrm{kg}$ ) is around 70 to $87 \%$.

- the rate of laboratories producing a satisfactory accuracy z-score for total SEM content around the MRPL (between 1.3 and $1.4 \mu \mathrm{g} / \mathrm{kg}$ ) is around 64 to $69 \%$.

Even if all false positive or false negative results have come from laboratories ( $T, Q$ and $X$ ) using ion trap MS instrumentation, it is not possible to see a relationship between the type of MS used and the quality of the results. The number of participants using ion trap MS is too small to allow to give a 
significant conclusion from this study. The evidence is given by 2 others laboratories ( $\mathrm{P}$ and $\mathrm{R}$ ) which used ion trap MS : Laboratory $\mathrm{P}$ showed satisfactory Za-scores for materials 4-2, 5, 6 and 7 and laboratory R obtained 2 satisfactory Za-scores for material 4-1 and 7 and 1 questionable for AOZ. The bad results are rather due to the operators only. Nevertheless, with our experiment in the field of residues analysis, it is clear that triple quadrupole analyser is the type of instrument the best suitable to obtain reliable quantitative results.

\section{Conclusions}

For the control of banned substances, the rate of false positive / false negative results is of primary importance for official residue control. False negative results have implications for health protection. False positive result leads to direct trouble for the producer. The rate of false positive / false negative results cannot be evaluated without binding it to the analytical limit of the methods and to the concentration levels of the incurred samples. From this proficiency study, 16 laboratories out of 20 found the correct compliant and non-compliant samples according to the Decision 2002/657/EC.

The quantitative analysis of this study is important too because it shows that all z-scores were not satisfactory for samples containing SEM or AOZ around the MRPL level. The participants who obtained unsatisfactory results have to find the causes of that fact. In order to harmonize the control of nitrofuran metabolites from a point of view of legal action, it is necessary that quantitative results are homogeneous around the MRPL level.

However, it should be stressed that decision limits CC $\alpha$ reported by the participants varied from 0.1 to $1 \mu \mathrm{g} / \mathrm{kg}$ except for one participant (for which CC $\alpha$ is $3.8 \mu \mathrm{g} / \mathrm{kg}$ for AOZ using LC/MS single quadrupole). They are in accordance with the MRPL.

This proficiency test was very useful providing for the first time an overview of the control of nitrofuran metabolites inside and outside EU. It allowed participants to check their ability to confirm analytes with their own routine method. From that point, participants can either prove the reliability of their 
results or either take measures to improve their method. To keep on with efforts on harmonization of control of nitrofurans metabolites residues in $\mathrm{EU}$, another proficiency test for nitrofuran metabolites in chicken is in progress.

\section{Acknowledgments}

C. Bock and P. Govik, BVL, Berlin, Germany ; M. Brandtner, AGES-VMMOE, Mödling, Austria ; Y. Govaert, Institut de Santé Publique, Bruxelles, Belgium ; M. Vahl, Danish veterinary and Food Administration, Soborg, Denmark ; P. Munoz Moreno, Centro Nacional de Alimentacion, AESA, Majadahonda, Spain ; L. Saari, National Veterinary and Food Research Institute, Helsinki, Finland ; E. Coni and G. Brambilla, Istituto Superiore Di Sanita, Roma, Italy ; J.A. Van Rhijn, RIKILT-DLO, Wageningen, The Netherlands ; P.R. Kootstra, RIVM, Bilthoven, The Netherlands ; J. Barbosa, Laboratorio Nacional de Investigacao Veterinaria, Lisboa, Portugal ; D.G. Kennedy, Veterinary Science Division, Belfast, UK ; T. Waglund, National Food Administration, Uppsala, Sweden ; T. Bigwood, Central Science Laboratory, York, UK ; K. Frgalova, ISCVBM, Brno, Czech Republic ; L. Kovacsics, National Food Investigation Institute, Budapest, Hungary ; J. Van De Riet, Canadian Food Inspection Agency, Dartmouth, Nova Scotia, Canada ; P. Edder, Service de Protection de la Consommation, Genève, Suisse ; Nguyen Anh Dung, National Fisheries Inspection and Quality Assurance Center, Ho Chi Minh City, Vietnam ; M. Hodge, Queensland Health Scientific Services, Coopers Plains, Australia.

\section{References}

Commission DeCISION 2003/181/EC, 2003, of 13 March 2003 amending Decision 2002/657/EC as regards the setting of minimum required performance limits (MRPLs) for certain residues in food of animal origin, Official Journal of the European Communities, L71, 17. 
Commission DeCISION 2002/657/EC, 2002, of 12 August 2002 implementing Council Directive 96/23/EC concerning the performance of analytical methods and the interpretation of results, Official Journal of the European Communities, L221, 8-3

Council Regulation (EEC) No 2901/93, 1993, of 18 October 1993 amending Annexes I, II, III and IV to Regulation (EEC) No 2377/90 laying down a Community procedure for the establishment of maximum residue limits of veterinary medicinal products in foodstuffs of animal origin. Official Journal of the European Communities, L 264, 1

Commission REgulation (EC) No 1442/95, 1995, of 26 June 1995 amending Annexes I, II, III and IV of Council Regulation (EEC) No 2377/90 laying down a Community procedure for the establishment of maximum residue limits of veterinary medicinal products in foodstuffs of animal origin. Official Journal of the European Communities, L 143, 26.

CoOper, K. M. \& KenNedy, D. G. 2005, Nitrofuran antibiotic metabolites detected at parts per million concentrations in retina of pigs - a new matrix for enhanced monitoring of nitrofuran abuse. Analyst, 130, 466-468.

ISO/DIS 13528 working draft document, 2000, Statistical methods for use in proficiency testing by interlaboratory comparisons.,

ISO/IEC Guide 43-1, 1997, Proficiency Testing by Interlaboratory Comparisons - Part 1: Development and operation of proficiency testing schemes.

Leitner, A., Zollner, P. \& LindneR, W. 2001, Determination of the metabolites of nitrofuran antibiotics in animal tissue by high-performance liquid chromatography-tandem mass spectrometry. Journal of Chromatography $A$ 939, 49-58.

Mottier, P., Khong, S. P., Gremaud, E., Richoz, J., Delatour, T., Goldmann, T., et al. ,2005, Quantitative determination of four nitrofuran metabolites in meat 
by isotope dilution liquid chromatography-electrospray ionisation-tandem mass spectrometry. Journal of Chromatography A, 1067, 85-91.

Thompson, M., and Wood, R., 1993, International Harmonized Protocol for Proficiency Testing of (Chemical) Analytical Laboratories, Journal of A.O.A.C International, 76, 926-940.

Thompson, M. 2000, Recent trends in inter-laboratory precision at ppb and subppb concentrations in relation to fitness for purpose criteria in proficiency testing. Analyst, 125, 385-386. 